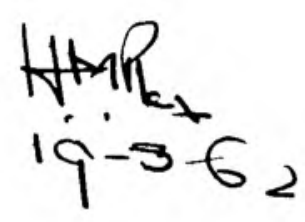

\title{
DIE SIN VAN DIE OPVOEDING
}

Wanneer 'n mens oor die sin van die opvoeding wil handel, is dit 'n allereerste vereiste dat die verskynsel van die opvoeding in sy suiwerheid raakgesien sal word, vry van wetenskaplike uitsprake en eventuele vooringenomenhede dienaangaande, vry van oogmerke daarmee en vry van psigologies-didaktiese aangeleenthede in die proses daarvan. Die verskynsel moet in sy essensie, in sy wesensuiwerheid en sy selfopenbaring geskou word. Oor hierdie verskynsel in sy suiwerheid moet gespreek en die sin daarvan probeer oopgedek en opgediep word. Met ,,die sin daarvan" kan velerlei bedoel word soos die betekenis, die eventuele strekking, die openbaring, die bekendwording, die oopdekking, die vertolking, die ontbloting, die weerkaatsing, die moontlike heenwysing, die duiding van die verskynsel. Onder ;,sin van die opvoeding" word hier verstaan die soektog na 'n antwoord op die vraag of die opvoeding as menslike daad-met-'n-ander nie wellig ' $n$ herinnering aan, ' $n$ verklanking van en 'n heenwysing na dinge is wat baie dieper as die verskynsel self lê nie en waarvan laasgenoemde alleen 'n sigbare uiting is.

Wanneer hieroor gehandel word, moet na die oordeel van die skrywer twee dinge duidelik besef word, naamlik dat ons hier met een van die diepsinnigste vraagstukke te doen kry waaroor besin kan word en tweedens dat die antwoorde wat dienaangaande gegee mag word, nie van 'n afdoende nie, maar van 'n soekende aard is. Daar kan nie gesê word dat die sin van die opvoeding presies dit en nie iets anders is nie. Anders gestel: dit is geen kwantitatief-bepaalbare, meet-, kontroleer-, herhaal- en verifieerbare aangeleentheid nie. Opvoeding in sy suiwerheid ontspring nie alleen uit die a-rasionele dimensies van die menslike bestaanswyse nie, maar ook elke verklanking wat dit voortbring en elke poging tot sinduiding daarvan verwys na dieper lae as die suiwer humane, om van die vegetatief-animale nie eens te praat nie. Wie byvoorbeeld meen dat die verskynsel uit die biologies-vitale dimensies van die menslike bestaan voortkom, het myns insiens nie alleen 'n eensydige nie, maar ook 'n onvolledige, verwronge en selfs verdraaide beeld daarvan.

Op hierdie stadium is dit noodsaaklik dat die verskynsel van die opvoeding beskrywe sal word. Hy moet in sy suiwerheid gesien word indien sy essensie en sy sin gepeil wil word. Nou is dit voorwaar geen gemaklike taak om die verskynsel in sy suiwerheid onder woorde te bring nie. Vir die gebreke en tekortkominge van die taal mag egter nie teruggedeins word nie. Aangaande die verskynsel moet eerstens opgemerk word dat dit een is wat onder mense en mense alleen aangetref word. Die dierelewe ken die 
verskynsel eenvoudig nie en geen mens-dierverhouding reflekteer die verskynsel nie. As verskynsel onder mense is dit van universele aard, waarmee bedoel word dat dit oral en altyd aangetref is en word. Een van die beste tiperinge van die mensbeeld is dat die mens 'n wese is wat opgevoed het en opvoed, opgevoed is en word, hom vir opvoeding geleen het en leen en op opvoeding aangewys was en is. As interhumane verskynsel van universele aard beperk dit hom tot die verhouding volwassenes - volwassene-wordendes, of eenvoudiger uitgedruk: dit is 'n grootmens-kind-, en geen kindgrootmensverhouding nie. Dit is verder ook nie 'n kind-kind- of 'n volwassene-volwassenverhouding nie. Anders gestel: die een kind kan nie 'n ander kind of die een volwassene' $n$ ander volwassene opvoed nie. Dit is en bly 'n grootmens-kind- verhouding waarby uitdruklik gekonstateer word dat die klem op die eerste lid van die verhouding val en dat die inisiatief vir die ontstaan van die verhouding by hierdie eerste lid geleë is. Opvoeding vind sy aanloop steeds by ' $\mathrm{n}$ volwassene en by geen ander as volwassene nie.

Aansluitend by die voorafgaande moet nadruklik daarop gewys word dat die grootmens-kindverhouding om as opvoedingsverhouding gekwalifiseer te word, 'n verhouding van 'n besondere soort moet wees. Die grootmens-kindverhouding sien ons heeldag, maar ons sien nie heeldag die opvoedingsverkynsel nie. Die moeder is by haar kleine, die ouers by hulle kinders, die onderwyser by sy leerlinge. Al hierdie en baie ander verhoudinge waarby volwassenes en kinders betrokke is, kan gewone omgangsverhoudinge wees en bly. Dit is gevalle van bewuste en onbewuste bymekaarwees. 'n Omgangsituasie is nog nie een waarby opvoeding betrokke is nie. Dit is byvoorbeeld moontlik dat 'n onderwyser die ganse skooldag by sy leerlinge kan wees en in weerwil hiervan myle ver van hulle en hulle van hom verwyder is. In hierdie bymekaarwees kan hy by hulle selfs 'n magdom wetenswaardighede met die oog op eksamendoeleindes van 'n hoogsparate aard ontwikkel. Wanneer sulks oorwegend die geval is, noem ek so iemand die verkondiger van blote eksamen- en salariswaarhede. 'n Mens kan goeie onderwys gee sonder om juis noemenswaardige opvoedingswerk te verrig!!

Om die opvoedingsverskynsel te laat ontstaan, moet die omgangsituasie een van ontmoeting word, d.w.s. die bymekaarwees moet 'n metmekaarwees word. Die grootmens moet 'n kind ontmoet. Hierdie ontmoeting kan aan die hand van velerlei middele soos die gesproke woord, mimiese en pantomimiese beweginge en uitdrukkingswyses bewerkstellig word, maar steeds met een doel, naamlik steungewing of hulpverlening op die weg van onvoltooibaarheid, onvolledigheid en onafgeslotenheid. Die ontmoeting duur nie ononderbroke voort nie; dit is 'n verskynsel wat kom en gaan, en van kortere of langere duur kan wees. Hoe dit sy: die opvoedingsverskynsel ontstaan daar waar ' $n$ grootmens hom tot ' $n$ kind in sy steunbehoewend- 
heid en steunsoekendheid wend. Hierdie wending geskied op bewuste, spontane en onverhoedbare wyse; dit kom voort uit 'n diepwortelende aangedrewenheid wat hom in liefdevolle oorgawe en wyding uit. Hierdie „Hingabe" vind sy ontmoeting in die warme liefde wat uit 'n kind se aangesig straal. Tuee menslike aangesigte ontmoet mekaar!!

Dit moet as een van die mees diepsinnige en misterievolle verskynsels in die menslike bestaan beskou word, die feit naamlik dat ' $\mathrm{n}$ grootmens hom tot ' $n$ kind wend. Stel u voor: 'n volwasse, gerypte en sedelik-selfstandige kultuurmens wend hom tot 'n kind, 'n onvolwasse, onrype en sedelik-afhanklike wese. Dit geld nie alleen vir die eie kind nie, maar ook elke ander kind, veral die kind in nood. Terloops: hier en nêrens elders nie lê die grondslag en die moontlikhede van die onderwys-beroep. Hierdie beroep impliseer immers dat elke kind ' $n$ kind te midde van en selfs in weerwil van die grootste beskerming en veiligste beskutting wat dit van volwassenes geniet en ondervind, deurgaans 'n kind in ewige nood is. Van opvoeding en dus van die onderwysberoep in sy mees verhewe sin sou niks tereggekom het indien die ewige nood van elke kind nie elke kind tot eie kind verhef het nie. Die vraag waarom elke kind eie kind vir die volwassene word, gryp nog dieper, want dit bring ook die ewige nood van die volwassene op die spel. Hiermee word sake egter reeds 'n bietjie vooruitgeloop. Hoe dit sy: dit is in verskynsels en probleme van hierdie aard dat na die sin van die opvoeding in sy essensie van ontmoeting tot steungewing gesoek moet word. Wat sou daar om of in 'n kind leef en gaande wees waartoe die volwassene aangedrywe word? Is 'n kind in sy staat van afhanklikheid en alles wat hiermee saamgaan dan inderdaad so 'n belangrike wese dat hy die aandag en selfs die toewyding van 'n volwassene kan afdwing? Vir die staat en die maatskaplike lewe in sy teenswoordige struktuur en werkwyse beteken die aandeel van 'n kind tog niks vir ekonomiese ontwikkeling nie en mag sy fisieke kragte nie geëksploiteer word nie, want kinderarbeid is in die ekonomiese lewe van die Weste iets van die verlede. Maar afgesien hiervan: kinders kan by wyle sulke lastige, rusverstorende en senuweeverrinnewerende wesentjies wees. Die aankoms van enige nuweling veroorsazak onder die mees normale omstandighede ontwrigting van die huislike roetine; ' $n$ kind is die berower van 'n mens se nagrus; hy verg gedurige aandag en daarby is hy die verwekker van kommer en sorg! Dit is selfs 'n bron van uitgawes! En tog: in weerwil van dit alles leer die ondervinding en bevestig die geskiedenis dat by elke normale volwassene die drang lewe om onbaatsugtige steun te gee ten einde te verhoed dat die verkeerde en die skadeberokkenende 'n kleine sal oorval. Elke verantwoordbare en respektabele volwassene kan nie oogluikend toesien en toelaat dat ' $n$ kind in gevaar sal verkeer, belaster, beskadig of getiranniseer word nie. Geen kind het 'n aansoekvorm voltooi om burger of burgeres van hierdie wêreld te word nie, maar wanneer hy eenmaal daar is, word sy aanwesigheid begroet en bejeën met die allerbeste wat daar in die mens 
losgemaak kan word, en dit afgesien van kleur, ras, geslag of geloof. Die onbevange sedelike bewussyn kan enige vorm van kinderverwaarlosing en -mishandeling nie sterk genoeg veroordeel nie. Wie vir 'n kind en trouens vir enige kind in die bres tree, geniet enige reggeaarde mens se hoogagting en bewondering. En wie 'n kind liggaamlik en geestelik opsetlik beskadig, word ' $n$ hoeveelheid verdiende leed gegun wat hewiger pyn en smart moet veroorsaak as wat deur enige regbank in die vorm van straf opgelê kan word. Het dit $\mathrm{u}$ al ooit getref dat wanneer $\mathrm{u}$ aan die stuur van $\mathrm{u}$ motor sit, u nie soseer bevrees is oor die beskadiging van hierdie duur besitting of dié van u mede-reisiger nie. Dit is goed wat herstel kan word. Maar hierdie goed kan 'n kind raak- of doodry. 'n Ander se kind is wel nie my kind nie, terwyl daardie ander wie se kind dit is vir sy kind se veiligheid behoort te sorg!! En tog: sodra daardie kind my weg kruis en sodoende op my pad beland, word dit eensklaps my kind en staan dit vir my rekening. Ek kan my onder geen omstandighede van my verantwoordelikhede teenoor daardie kind, en trouens enige kind, losmaak nie.

Daar mag diegene wees, en trouens daar is diegene, wat met die reeds gemaakte stelling geen genoeë hoegenaamd sal neem nie. Volgens hulle is daar niks buitengewoons en beslis niks misterievols in die daarwees van 'n kind nie, nog minder in die wending van 'n volwassene na 'n kind! Dit dui op niks buitengewoons nie, en wie in die bymekaarwees en selfs die sogenaamde ontmoeting van 'n volwassene met 'n kind die verklanking sien van iets wat die ervaring oorskry, maak hulle aan grootste illusies skuldig! Die daarwees van ' $n$ kind is die resultaat van die werking van biologiesvitale kragte waardeur dit gemotiveer en gedra word. Net soos die geboorte ' $n$ biologiese verskynsel is, so is ook die versorging van 'n kind met insluiting van sy opvoeding 'n biologiese aangeleentheid! Opvoeding is alleen die oriëntering in tegnieke om die omgewingsproblematiek te beheers, want die hele bestaan van die mens laat hom kenmerk deur 'n proses van aktiewe inpassing en aanpassing by die gedurige en vinnig-veranderende sosiale en ekonomiese problematiek wat op hulle beurt weer onderlê word deur die noodsaaklikheid van beheersing van die omringende natuurlike wêreld! Dit mag so wees dat die opvoeding van beroep hom in sy beroepswerk tot 'n andermanskind kan wend maar dan geskied hierdie wending op een of albei van twee gronde: die opvoeder moet uit sosiale en ekonomiese oorweginge en verpligtinge die kind help om die nodige beheersingstegnieke te ontwikkel, ten einde positief en konstruktief aan die beheersing van die natuurlike wêreld mee te doen, óf die volwassene bemoei hom met ' $n$ kind op grond van psigologiese motivering en wel uit hoofde van 'n gevoel van minderwaardigheid. Wat sogenaamd as ontmoetinge tussen volwassenes en kinders, veral in beroepsverband bestempel word, is eintlik maar 'n wrekingsproses op 'n klompie weerlose kinders. In die rol van grootmeneer wat gespeel word, kompenseer die opvoeder vir 'n ingebore of verkreë gevoel van minderwaardigheid. Om met ' $n$ kind te 
assosieer en dié te ontmoet, is die openbaring van 'n onvermoë om met eie porture mee te ding en probleemsituasies te beheers. Volgens die beskouing van ekstremistiese psigo-analitici ly elkeen wat hom in beroepsverband met kinders besig hou, aan 'n minderwaardigheidskompleks.

Teen die voornoemde beskouingswyses hoef inderdaad geen kritiek gelewer te word nie. Net dit: die aard en die essensie van 'n geslaagde ontmoeting tussen 'n volwassene en 'n kind vloek na my oortuiging teen enige en elke opvatting wat pretendeer dat dit dié uiting van minderwaardigheid is of dat menslike verhoudinge by uitnemendheid deur seksueel-biologiese kragte gedra word. Omdat ons alles wil verseksualiseer en verbiologiseer, en tegelyk 'n geheime vrees vir minderwaardigheid het, sit ons met 'n seks- en 'n egskeidingsprobleem opgeskeep en dan kerm en kla ons oor die gedrag van ons jeug!! Maar genoeg hiervan en terug na die ervaringsfeit dat ' $n$ volwasse kultuurmens hom tot ' $n$ kind wend.

W'anneer oor die so-ewe genoemde feit nagedink word, kan 'n mens tot geen ander gevolgtrekking hom nie as dat 'n kind kragte by 'n volwassene moet losmaak wat na verborge dieptes in die menslike bestaan heenwys. Ek wil so ver gaan om te beweer dat hierdie bestaan sonder kontakte met 'n kind, dit sy die eie of dié van 'n ander, 'n berowing op die dieptes en die hoogtepunte van menslike bestaan beteken. Laat my dit so stel: wie hom met 'n kind bemoei en hom na daardie wese afbuig, - of moet 'n mens nie miskien sê: tot 'n kind verhef nie? - ervaar in hierdie verheffende afbuiging iets van die diepste roersele wat menslike geroepenheid onderlê. En wanneer hierdie wending een van wydende oorgawe word, speel elke komponent in die menslike samestelling sy rol. Die dieptes wat die essensie van menswees en menslike geroepenheid verklank, word oopgedek. U moet nie hieruit a flei dat ek 'n kind tot die god of die afgod van 'n volwassene verhef of dat ek die voorstander van kinderlike soewereiniteit en majesteit is nie. Die stelling word alleen gemaak dat indien ' $n$ mens die werklike dieptes van menslike bestaan wil peil of aanvoel, jy op die een of ander tyd met ' $n$ kind te doen moet kry en veral met dié dinge wat die kinderlike grootwording en grootmaking meebring. Die ondervinding leer dat enige volwaardige volwassene bereid is om te offer en op te offer in belang van 'n kind. Daar word gegee, dikwels teen alle vermoëns en selfs 'n mens se beterwete. Ons verwek kinders en ons is intens verheug oor hulle daarwees, maar tegelyk vul hulle ons lewe ook met die rykdomme van kommer en sorg. Skuldbesef en verantwoordelikheid word aanvaar en dit is asof hierdie dinge dieperliggende behoeftes losmak om vreugdemomente te word, selfs waar leed en lyding hulle onvermydelike opwagting maak. W'aar' $n$ kind is, daar is ook kommer en kwelling en is dit eenvoudig 'n onvermydelikheid dat daar vroeër of later geoffer en gely sal moet word. Elke ouerpaar weet dat in die verwagting en die aankoms van 'n nuweling te midde en in weerwil van die vreugde daar 
ook toekomssmart verborge lê en dat by die intenste belewinge van vreugde die lyding steeds by die deur lê en loer. Die vreugde sal met noodwendigheid ook vir die smart plek moet ruim.

Die vraag ontstaan onwillekeurig of ons dan kinders verwek om swaar te kry en om in hierdie onvermydelike swaarkry as ' $t$ ware ons lekkerkry te kry. Die getuienis dui daarop dat die lewe eers werklike diepte kry wanneer daar met 'n kind gelewe, vir 'n kind gestry en om 'n kind gely word. Hoe groter die opoffering en hoe intenser die leed wat deur teleurstelling, siekte en selfs die dood meegebring kan word, des te groter is die verdieping. Niemand sal sy deurleefde leed ter wille van 'n kind vir enige rykdom ter wêreld wil verruil nie, want die loutering wat deur leed en lyding teweeggebring word, vul die siel met die grootste geestelike rykdomme. Diegene wat geen kinders het of selfs nie wil hê nie, verdien inderdaad enige welmenende mens se meegevoel. Hulle mag huislike rustigheid en goeie nagrus geniet, selfs ekonomiese bates vergader. 'n Mens kan jou egter moeilik voorstel dat daar nie by wyle ook diepe ongeluk en onrus op die bodem van hulle siel lewe nie, die hunkering naamlik om ten behoewe van 'n kind op te offer en te ly. Die mens het behoefte aan lyding en wyding, en wie bereid is om hierdie dinge vir ' $n$ kind deur te maak, besit skuldbesef as verantwoordelikheid, en wie hieroor beskik, onderskrywe die sinvolheid van mensebestaan. Dit wil my inderdaad voorkom dat 'n mens jou geloof in die sinvolheid van mensebestaan nie alleen behou nie, maar kan herwin wanneer daar met 'n kind gelewe en vir 'n kind gely word. Hierdie gedagte moet nog sterker gestel word: die sinvolheid van mensebestaan kom nie voort uit biologies-vitale behoeftes en kragte nie, nog minder aan die hand van beheersingstegnieke en die eventuele rykdomme wat daardeur vergader word nie en les bes nie op grond van kennis en wetenskap nie, maar in die aard van jou verhouding met die medemens, by uitnemendheid in jou ontmoetingsbelewinge met ' $n$ kind. Ek wil dit as my eerlike oortuiging en as een van my onwrikbaarste sekerhede uitspreek dat die warme liefde wat 'n mens in die waaragtige ontmoeting met 'n kind ondervind, dit sy die eie of 'n andermanskind, jou onmiddellik laat aanvoel dat menslike bestaan geen noodlotsbestaan is nie. Daar word iets verklank wat in verband met menslike herkoms, geroepenheid en bestemming staan. Elke geslaagde ontmoeting tussen twee volwassenes veronderstel en vereis eksistensiële beslissinge van beide. Dit is bewuste plekwisseling as skuldbesef en medeskuldigheid nie alleen teenoor mekaar nie, maar teenoor groter magte wat in die mens ten behoewe van die mens werksaam is. Twee volwassenes kyk mekaar in die aangesig en hulle bely hulle oerskuld. Dit is ' $n$ aangrypende gedagte wanneer ' $n$ mens probeer peil wat inderdaad besig is om hom af te speel wanneer man en vrou mekaar eksistensieel ontmoet en wanneer onder andere die skaamte in eerbied wyk. Maar nog aangrypender is die gedagte wanneer 'n volwassene nie deur bewuste plekwisseling as skuldaanvaatding met 
'n ander volwassene mekaar in die aangesig staar nie, maar om 'n kind, onbewus van sy eksistensiële nood en medeskuldigheid, in die aangesig te kyk en dat die aanskoude hom nie alleen vasgegryp en veilig voel in die beskermende en beskuttende liefde wat hy van die volwassene geniet nie, maar dat die volwassene in sy omgang met 'n kind sy skuldigheid teenoor daardie kind besef. So gesien. is die ontmoeting tussen 'n volwassene en 'n kind geen gewone en alledaagse verskynsel soos die drink van 'n glas water by dorstigheid of die gaan rus by vermoeidheid nie. Anders gesê: die ontmoetingsfenomeen waaruit die opvoeding voortkom, mag te nimmer as 'n uiting van biologies-vitale behoeftes gesien word nie, maar steeds as 'n verklanking wat in verband met menslike herkoms, geroepenheid en bestemming staan.

Die groot vraag is nou waarop hierdie ontmoeting tussen 'n grootmens en 'n kind dui. Waaraan herinner dit en waarop wys dit eventueel? Soos reeds gesê, is 'n afdoende antwoord nie moontlik nie. Elke antwoord is en bly 'n soekende. Finale uitsluitsels bestaan net nie!! En hoe goed is dit dat die menslike bestaan en die verhoudinge wat tussen mense ontstaan, in geen formule of sisteem vasgelê kan word nie!! Indien die mens homself en sy verhouding met ' $n$ ander in afdoende sin sou verstaan, dan het die bekorende, die ewig-lokkende, die aangrypende en die eschatologies-verontrustende daaruit verdwyn. Dan het dit die vlak van die kousaal-meganiese bereik, en wanneer dit bereik is, dan het geloof en vertroue vir die wetenskap plek gemaak. En wanneer die mens sy lewe van geloof en vertroue selfs vir die ideaal van wetenskap verruil het, dan is een van sy belangrikste fasette, inderdaad die allerbelangrikste, ondergeploeg. Trouens, ons lewe nie uit die wetenskap nie, maar uit geloof en vertroue. Dit is juis in die lig van hierdie meer as kousaal-verklarende, hierdie kenning- en kennisoorskrydende dat ons bestaan sy profetiese inslag behou en ons ook van die paradoksale bewus word.

Word daat in en deur die ontmoeting van 'n grootmens met 'n kind of selfs van twee volwassenes iets verklank? Verwys dit na iets en herinner dit aan iets? Dit is lastige vrae, maar hulle is eenvoudig onvermydelike vrae waarvoor enige opvoedkundige en opvoeder van beroep, as hy sy sout werd is, geplaas word en waarop hy 'n antwoord verskuldig is. Daar kan met sekerheid gekonstateer word dat die ontmoeting in sy essensie ondubbelsinnig iets verklank, aan iets herinner en na iets heenwys. Die beslistheid waarmee hierdie konstatering geskied, is egter geen rasioneel-bewysbare aangeleentheid nie; dit is geen denkende ontrafeling nie, maar die uiting van 'n bepaalde visie of siening op menslike bestaan. Ons opvatting oor die sin van die opvoeding hang saam met ons lewensopvatting. Dit is die neerslag daarvan. Deurgaans moet in die gedagte gehou word dat ons verhoudinge tot andere deur baie min wetenskaplikheid gekenmerk word. Hierdie verhoudinge word deur kragte en magte gedra 
wat dieper reik en oneindig verder strek as kennis en wetenskap. Dit is histories-ideologiese aangeleenthede, en as ons dit met mekaar eens sou wees oor wat vertolk word, dan is dit geensins omdat ons so vindingryk of skerpsinnig is nie, maar omdat ons uit 'n gemeenskaplike erfenis leue. Ons is baie groter erfgename as wat ons wetenskaplike erflaters is en soos so-ewe gesê is: ons lewe is geen wetenskaplike gemotiveerde aangeleentheid nie, maar vind sy stukrag in die opeisende krag van die lewensopvatting met sy implikasies as beginsel van interpretasie vir daardie so merkwaardige verskynsel, naamlik dat ' $n$ volwassene hom met ' $n$ kind bemoei.

Ons is Westerlinge en ons is .Europeane wat uit 'n kultuurhistoriese erfenis lewe wat oor baie eeue bewaar is. Drie magte het Europa gemaak wat hy is en het dus ook vir ons gemaak wat ons is, naamlik Athene, Rome en Jerusalem, met die nadruk op Jerusalem. Daar is die Griekse lewensvisie met sy oorwegend rasionalisties-idealistiese inslag; daar is die erfenis uit Rome by monde van die regspraak wat die onderlinge gedragsreëling van die Westerse mens nie onbeinvloed gelaat het nie en daar is Jerusalem met sy unieke gedagte van skepping, sondeval, herskepping en eindverwagting. Hierdie drie magte het geïntegreer, maar ook gedifferensieer. Integrasie, maar veral differensiasie het meegebring dat baie ombuiginge, vertakkinge, vervlakkinge, verdiepinge en veranderinge met aksentuering van die nuwe plaasgevind het. Dit is ' $n$ geskiedenis van hoogtepunte en mislukkinge, van oorwinning en van neerlaag, van krisis op krisis sonder dat een enkele hiervan blywend oorwin is. Dit ten minste het die oueres onder ons sedert die jongste eeuwenteling met eie oë aanskou. Oor die feite dienaangaande hoef hier nie gehandel te word nie. Hulle kan deur elkeen wat hom die moeite wil getroos, self nagegaan word. In ieder geval: die geskiedenis van die Weste is iets anders as die geskiedenis van die tye van opkoms en ondergang van die son en maan, van eb en vloed, van oorstrominge en droogtes, van sons- en maansverduisteringe, van rekords op sportgebied en sulkes meer. Die geskiedenis van die Weste is die geskiedenis van die idee aangaande die mens, sy plek en sy taak in die groot kosmiese totaliteit. Dit is die geskiedenis van die antwoord op die vraag na twee groot sake: die vraag na die lewenswaardevolle en die vraag na die sin van die geskiedenis waarin die mens opgetree het.

Nou mag dit as sonderling voorkom dat die twee genoemde sake wat skynbaar vreemd aan mekaar is, hier as 't ware in een asem genoem word om dan van hieruit 'n antwoord op die vraag na die sin van die opvoeding te gee. U sou byvoorbeeld met reg kan vra wat die filosofie van die geskiedenis met die opvoeding te maak het, om van die sin daarvan nie eens te praat nie. U kan ook verder vra watter vetband daar tussen die filosofie van die geskiedenis en die vraagstukke van lewensopvatting geleë is. Dienaangaande moet nadruklik gekonstateer word dat hierdie dinge alles met mekaar te maak het. So byvoorbeeld bepaal 'n mens se lewens- 
opvatting jou visie op die geskiedenis, terwyl iemand se siening op die geskiedenis direk en indirek bepaal wat daar gedoen behoort te word. Terloops: die filosofie van die geskiedenis is vanselfsprekend iets totaal anders as die feite van die geskiedenis in hulle min of meer chronologiese volledigheid. Dit is die besinning oor daardie feite wat deur menslike optrede tot stand gekom het om daaruit die aard van die houding van die mens teenoor die werklikheid te bepaal. Die antwoord op die vraag na die sin van die geskiedenis probeer om uitsluitsel te gee oor die staanplek en die taak van die mens in hierdie kosmiese totaliteit. Sodra daar van 'n takopgawe sprake is, word dit 'n saak van opvoeding, want wie opvoed, verander bewus die lewensuitinge van die opvoedeling in die rigting van die lewenswaardevolle in rangorde van voorkeur wat behoort te klop met sy interpretasie van die sin van die geskiedsdrama. Wat is die geskiedenis van die opvoeding anders as die antwoorde wat oor die loop van die eeue op twee vrae gegee is, naamlik die sin van die geskiedenis en die staanplek en taak van die mens in hierdie wêreld?

Indien ek dinge reg sien, dan huldig die Weste drie groot beskouinge oor die sin van die geskiedenis en ook dieselfde aantal visies oor die lewenswaardevolle. Immers, wie die geskiedenis as ideëgeskiedenis raadpleeg, sal moet toestem dat drie groot tipologieë van lewensopvatting vir DIE WESTE onderskei kan word. Dit beteken dat daar ook 'n drietal visies op die sin van die opvoeding moet bestaan en wat myns insiens inderdaad ook die geval is. Oor elkeen van hierdie visies word vervolgens enkele opmerkinge gemaak.

Die eerste beskouing oor die sin van die geskiedenis is dié van die reguitlyn of van die liniêre beweging. Hierdie idee van die reguitlyn het geen vaste begin en ken ook geen vaste of finale eindpunt nie. Hierdie lyn besit ' $n$ voorwaartse beweging met die gang van die geskiedenis. Die rigting van die lyn is onbekend, want die geskiedenis van die mensheid is die geskiedenis van 'n eksperiment wat voortdurend aan die gang sal bly. Die lyn vertoon veranderinge wat in hulle sosiale doeltreffendheid as verbetering en vooruitgang bestempel word.

Hierdie beskouing is van besonder resente datum. Dit dagteken sedert die Renaissance van die $15 \mathrm{de}$ en $16 \mathrm{de}$ eeu en hang met die opkorr s van die moderne natuurwetenskap baie nou saam. Hierdie visie het oor die afgelope vyf eeue geweldige vooruitgang gemaak en skyn nie alleen die geeste te bekoor nie, maar selfs te oorweldig. Immers: vooruitgang is sowel die motto as die credo van die moderne en die kontemporêre mens. As tipe van lewensopvatting is dit ' $n$ uitgesproke scientisme waaronder verstaan moet word 'n verwetenskapliking en veral natuurverwetenskapliking van alles. Hierdie scientisme openbaar hom in 'n materialisme, 'n ewolusionisme, 'n biologisme, 'n positiwisme, 'n pragmatisme, 'n instrumentalisme en 'n sogenaamde progressiwisme. In die taal van wyle prof. KoнNSTAMm kry 'n 
mens hier te doen met die houding van heers-oor die werklikheid. Een van die uitstaande eksponente van hierdie denkrigting, naamlik WILLIAM Kilpatrick, sê byvoorbeeld dat twee gebeurtenisse van deurslaggewende belang vir die geestesgeskiedenis van die Weste is, te wete Galilel se eksperimente vanaf die leunende toring van Pisa en die verskyning van DARwiN se Origin of Species. Vir die liniêre geskiedbeskouing en die daarmee korresponderende lewensopvatting is die mens die produk van ontwikkeling. Die mens bevind hom in die wêreld; hy is van die wêreld en vir die wêreld. Nie alleen moet hy hom in hierdie wêreld oriënteer nie, maar dit ook leer ken ten einde probleemsituasies te beheers. Die geheimenisse van die natuur moet ontrafel word om dié in die diens van menslike vooruitgang aan te wend. Die mens is 'n organisme wat in aktiewe responsie met sy omgewing verkeer. Hy moet hom by sowel die eise van sy natuurlike milieu as die snelveranderende sosiale en ekonomiese toestande aanpas. Aanpassing is 'n lewenswet en geslaagde aanpassing word bevorder deur suksesvolle beheersing van probleemsituasies. Kennis en wetenskap is onfeilbare waarborge vir die beheersing van probleemsituasies en meteen ook vir die bevrediging van menslike behoeftes.

Wat sou die sin van die opvoeding in die lig van die genoemde feite wees? Opvoeding verklank niks, dit herinner aan niks en dit wys heen op niks wat van 'n ervaringsoorskrydende aard is nie. Dit word uit 'n sosiaalbiologiese eis gebore naamlik aanpassing by die natuurlike en die sosiale milieu, en beheersing van daardie milieu ten einde biologies staande te bly. Die opvoeding het 'n doel, naamlik die hulpverlening tot meer en ryker lewe wat geleë is in 'n proses van voortskrydende situasiebeheersing, ekonomiese beplanning en vooruitgang. Dat die ontmoeting tussen ' $n$ volwassene en 'n kind iets van menslike geroepenheid verklank en elemente van 'n ervaringsoorskrydende aard inhou, is loutere illusie. Dit het geen sin nie, slegs ' $n$ taak en dié is hulpverlening tot situasiebeheersing en sosiale bruikbaarheid. Soos gesê: die mensheid is met 'n grootse eksperiment besig. Hy soek die waarheid en die waarheid wat hy reeds het, word deur bruikbaarheid vir beheersingsdoeleindes gekenmerk. Dit is seker nie nodig om daarop attent te maak nie hoe deurtrek ook ons Suid-Afrikaanse opvoedingswese met hierdie heersoor-en beheersingsgedagte is, hierdie liniêre geskiedsbeskouing. Dit is hier nie die plek om ons Suid-Afrikaanse onderwyswese onder die soeklig te neem nie, maar tog moet opgemerk word dat wanneer dinge grondig deurdink word ons tot die ontdekking sal kom dat ons deurgaans op 'n dualisme ry, ten minste wat betref die Afrikaanse deel van die bevolking. In die beste van oomblikke huldig ons 'n visie wat ander praktiese implikasies verg as wat deur 'n scientisme geimpliseer word.

Die tweede visie op die geskiedenis is dié van die kringloop - die gedagte van die herhaling of die idee van die ewige terugkeer van die dinge. 
Hierdie gedagte het baie variasies, maar kom in hoofsaak tog daarop neer dat die wêreldgeskiedenis die voorkoms van 'n sirkel het. Die aardse gebeure loop af volgens die aanwysing van die vinger van God en hierdie vinger beskrywe 'n sirkel, 'n op- en neergang wat die mensheid in sy gang meevoer. Aan die begin van die tye is daar 'n toestand van volmaakte saligheid waarna 'n periode van verval intree. Hierdie verval lei na die dieptepunt van verwording wat in die reël saamval met 'n tydstip waarop die profeet die Godspraak verkondig. Hy kondig die lot van die volk aan en sê wat sal kom op grond van sy wete van wat voorafgegaan het en wat reeds voorspel is. Wanneer na hom geluister en sy raadgewinge gevolg word, is elke dieptepunt tegelyk 'n keetpunt. Op die neergang sal die opgang volg waardeur die weg gebaan sal word vir die herstel van die Ewige Vrede wat eenmaal was en weer sal word indien die volk sy deur God gewilde bestemming wil bereik.

Die gedagte van die kringloop tref ons ook aan by die China van Confucius. Die goue tydperk van die verlede is altyd die gedroomde paradys waarheen die hart trek en die gedagtes strewe. So het Confucrus geleer dat die goue tydperk van volmaakte geluk en volstrekte harmonie eenmaal werklikheid was en wel toe die vrome voorvadere gelewe het. Omdat die verdwaasde mensheid hulle goeie raadgewinge in die wind geslaan het, het verval ingetree wat alleen die hoof gebied kan word indien uit hierdie geheiligde tradisie met sy bekende voorskrifte weer die maatstaf betrek kan word van wat behoorlik is vir die mens op alle lewensgebiede. Ook die klassiek-Griekse geskiedenisbeeld is siklies. Die beskouing oor die geskiedenis was nie dié van 'n liniêre ontwikkeling vanaf 'n bepaalde toestand verder die toekoms in nie, maar dié van die ewige ontstaan en vergaan. Alles wat bestaan, is ' $n$ herhaling van die bestaan soos die opkoms en die ondergang van die son, die wisseling van die getye en jaartye. Hierdie dinge wek die idee van tydelike veranderlikheid teen die agtergrond van konstantheid en onveranderlikheid. Die blywende reëlmaat soos wat in die hemelliggame opgemerk word, was vir hulle van groter waarde en interesse as die idee van 'n progressiewe en radikale verandering. In 'n geestelike klimaat van hierdie aard pas die idee van 'n absolute beginen eindpunt glad nie, ook nie die gedagte van 'n enkele sentrale gebeurtenis wat $\sin$ en waarde aan sowel die verlede as die toekoms kan verleen nie. Die verlede is ' $n$ vaste en blywende gegewenheid, terwyl die gebeurtenisse van die toekoms dieselfde patroon sal volg as wat in die verlede die geval was.

Hierdie geskiedsvisie het sy parallelle in die idealisme as filosofiese stroming. Hier leef nie die gedagte van heers-oor die werklikheid nie, maar dié van opgaan daarin en die eenwording daarmee. Die grondhouding van die opgaan-in vind uitdrukking in die oortuiging dat die eie heil en dié van ander daarin geleë is, naamlik om jouself as ' $t$ ware te verloor en in 'n 
onpersoonlike wêreldgrond op te gaan. Die indiwiduele mens word gesien as 'n tydelike verskyning uit die groot geheel. Sy bestaan is 'n projeksie uit die wêreldsiel. Hy is soos 'n eilandjie wat vir 'n klein rukkie op die oppervlakte van die oseaan verskyn en dan weer verdwyn. Alle strewe word gekenmerk deur ' $n$ universalistiese tendens, 'n drang tot eenwording met die geheel. In hierdie drang wat 'n steeds groeiende tot groter eenwording is, verdwyn die persoonlike en is daar van 'n Persoon as selfstandigheid eintlik geen sprake nie. Die skerpe teëstelling tussen bewussyn en werklikheid of tussen gees en natuur wat so kenmerkend van die Wes-Europese werklikheidsinstelling is, verval grootliks. Dit is die werklikheiḑshouding van die Sentraal-Europese gees, by uitnemendheid dié van die Oosterse denke, wat hierdie eenheidsband met die werklikheid so sterk handhaaf en benadruk.

Die idealisme poneer die prioriteit van die gees teenoor die stof, vandaar die konsekwente tweeledige eis: vergeesteliking of kultivering van die natuurlike ook in die mens en intuitiewe partisipasie met die idee. Opvoeding is inleiding in, en inlywing by die waardevolle kultuurgoed. Alle pedagogiek is waarde- en kultuurpedagogiek. Die siel van alle kultuur is die kultuur van die siel, die bereidwillige gehoorsaamheid om uitdrukking te gee aan die idee van die kultuur. Die denkbeelde van pedagogiese grootmeesters soos Herder, Froebel, Eucken, Nohl, Messer, Spranger en 'n ry ander is deurdrenk hiervan.

Wat is vir die idealisme die sin van die opvoeding. Iemand soos SPRANGER benadruk konsekwent dat die verskynsel van die opvoeding deur 'n daad, keuse of beslissing van die kant van die opvoeder bewerkstellig word. Laasgenoemde lewe onder die gesag van die wekroep wat van die waardes as geobjektiveerde kultuur uitgaan. Die opvoeder weet van 'n "Seinsollen", die eise van behoorlikheid, en staan hy onder die gesag van die opeisende krag daarvan. Daar moet bemoeienisse met die opvoedeling gemaak word. Laasgenoemde in sy proses van grootwording loop steeds gevaar om ontspoor te raak. Die opvoeder moet die opvoedeling in die te worde verbondenheid met en gehoorsaamheid aan bepaalde kultuurwaardes behulpsaam wees. Dit is in die lig hiervan dat hy die opvoeding omskrywe as daardie wil wat in gehoorsaamheid aan die wekroep van die waardes tot die siel van 'n ander aangevuur word om by hierdie ander ontvanklikheid en geesdrif vir besondere waardes te wek, sodat hierdie ander van binne-uit vormgewend in die rigting van daardie besondere waardes kan ontvou. Die opvoederspersoonlikheid moet steeds onder die besef van die noodsaaklikheid van inpassing van sy opvoedelinge in die synsverband van die behoorlike sy werk verrig.

Die idealisme huldig sy beskouinge oor die sin van die opvoeding. By 'n noukeurige besinning oor sy grondgedagtes wil dit voorkom asof oor die breë linie gesien, die volgende 'n samevatting daarvan kan wees. Eer- 
stens: die ontmoeting tussen opvoeder en opvoedeling verklank die gemeenskaplike verbondenheid van beide met die groot geheel. Daar leef en werk die besef van saamhorigheid met die geheel van alles wat is en die drang om een te word met die groot geheel. Hierdie universalistiese tendens dwing die opvoeder om sy belange via dié van 'n kind ondergeskik te maak aan die belange van die geheel. Tweedens leef die besef dat die mens in sy toestand van nimmereindigende onderwegwees steeds voor beslissinge staan en dat hy deur die aard van die beslissings elke oomblik remmend of bevorderend inwerk op die geheel derhalwe en vir die toekoms, ook van dié van die opvoedeling, mede-verantwoordelik is. Derdens leef daar die besef dat hy nie alleen staan nie, maar hoëre magte en diepere gronde tot steun en bondgenoot het wat die versekering waarborg dat elke daad van gewillige oorgawe en wyding aan die belange van 'n kind gehoorsaamheid aan die opdrag van menslike geroepenheid as die vormgewer van die idee van die mens is. Die leser sal dit gewonne gee dat indien hierdie interpretasie van die idealistiese visie op die sin van die opvoeding korrek is, dit mooi dinge is wat hierdeur aan die lig tree. Ons moet ons net nie wysmaak dat die idealisme as werklikheidsbeskouing in ons Suid-Afrikaanse opvoedingswese leef nie. Dit is net nie daar nie, wel miskien in sy praktiese opset, maar dan ook myns insiens baie sporadies. Ons moet in die gedagte hou dat ons die erfopvolgers van die Wes-Europese geestesinstelling is.

Die derde en laaste siening op die geskiedenis bevat sowel die gedagte van die reguitlyn as dié van die kringloop. Dit is egter geen sintese van beide nie, want hierdie visie sintetiseer eenvoudig nie. Hy is en bly wat hy is, en hy is abosluut. 'n Mens kan dit noem die gedagte van die kringloopin-reguitlyn-gebeurende vanaf 'n vaste begin na 'n absolute eindpunt. Die vaste beginpunt van die wêreldgeskiedenis is die skepping, opgevolg deur die sondeval, met die belofte van herskepping wat plaasgevind het by die grootste gebeurtenis in die wêreldgeskiedenis, naamlik die geboorte van Christus wat 'n loodregte inbraak vanuit die Ewigheid op die tyd was met die finale en absolute eindpunt, naamlik Sy wederkoms. Daar is 'n vaste beginpunt, naamlik die Skepping en daar is 'n absolute eindpunt, te wete die voleinding. Die reguitlyn word deur hierdie twee vaste punte getermineer. Ergens op hierdie lyn staan 'n Baken of Teken, naamlik die Kruis, waarvandaan 'n mens terug- of skeppingwaarts, maar ook toekomswaarts kan kyk. Die Vleeswording van Christus verdeel die geskiedenis in twee: wat vooraf gebeur het, is 'n beweging na en 'n heenwysing op die geboorte van Christus. Wat daarna gebeur, is die afwagting van die wederkoms van Christus. Hierdie liniêre beskouing beskrywe vanself 'n kringloop wat egter eers by die wederkoms van Christus voltooiing sal bereik. Op die liniêre lyn self kan een voltooide siklus onderskei word, naamlik die vervulling van die belofte by die verlies van die Ewige Vrede in die Paradys. Verder is daar die sig steeds herhalende kringloop soos die opkoms 
en die ondergang van kulture, hoogte- en dieptepunte in menslike bestaan, die verskynsels van die geboorte en die dood in die bestaan van enkelinge. Die geskiedenis herhaal hom nie meganies in vaste vorm op die groot patroon nie, want daarvoor is die aandeel van menslike wil en opset te groot. Die materiaal vir die patroon bly egter dieselfde, naamlik sonde en vervloeking met die belofte van die Ewige Vrede wat met die Voleinding sy intog sal maak. Die koms van Christus was inderdaad die radikale verbreking van die sekulêre geskiedenis, want dit was 'n deurbraak uit die Ewigheid op die tyd en wat meer is: Sy koms uit die gebied van die GansAndere was ' $n$ boodskap en opdrag aan mense en geen visie van mense nie. Die grondtoon van die boodskap is die aanwysing van die weg tot deelgenootskap aan die Ewige Vrede. Dit gaan om God se liefdesbemoeienis met die gevalle mens en Sy bereidwilligheid om nie alleen by die sondaar te woon nie, maar hom uit genade as kind aan te neem.

Die so-ewe gesketste geskiedsvisie is die parallelle van die teîstiesgeoriënteerde rigtinge van lewensopvatting. As visies is daar meteen baie variasies en tog is die gemeenskaplike daarin dat 'n persoonlike God die oorsprong en die bron van die werklikheid is, dat die mens geskapene deur God is, dat hy gevallene geword het en is, dat God mens geword het ter wille van die mens, dat God in Christus-Jesus deur mense gekruisig is en dat in weerwil hiervan die geskiedenis vanuit die visie van die Kruis heilsgeskiedenis is. Die Kruis herinner aan 'n wêreld wat eenmaal goed was, maar weer goed sal word. Die Bybel vanaf Genesis tot Openbaring bevat nie alleen die gedagte van Skepping, Herskepping en Voleinding nie, maar vra ook dat die liefdeswonder van God vir die mens een van barmhartigheid van die mens tot sy medeskepsel sal wees. Die mens bestaan as kreatuur van God onder en tussen sy medeskepsels en moet elkeen die medemens as medeskepsel sien wat deur God op sy pad geplaas is en teenoor wie hy verantwoordellikheid verskuldig is. Dit is geensins ' $n$ geval van heets-oor of van opgaan-in die werklikheid nie, maar van liefhê.

Watter vertolking gee hierdie visie aan die verskynsel van die opvoeding en wat kan in die lig hiervan die sin daarvan wees? So-ewe is die opmerking gemaak dat Christus deur mensehande aan die Kruis geslaan is. $\mathrm{Na}$ regte moes die mens opgehou het om mens te wees, want sinds Adam vlug die mens voor God. Hy moeș ook enige en elke konfrontasie met sy naaste vermy en sy aangesig bedek het. En tog kyk ons mekaar in die aangesig. Die gelowige herken die beeld van God in elke ander, maar tegelyk herken hy in elke gesig wat hy aankyk, sy eie skuld en medeskuldigheid aan die dood van Christus. In stede van sy gesig weg te draai, bemoei hy hom bewus en opsetlik met daardie ander wat in so baie gevalle vir hom volslae vreemdeling is. Is dit nie verregaande brutaliteit en vermetelheid om die medeskepsel in die aangesig te kyk, veral 'n kind wat van sy medeskuldigheid nog onbewus is? Of sou die ontmoeting tussen volwassenes 'n 
verklanking van die kruisboodskap wees? En as dit so is, dan moet die ontmoeting tussen 'n grootmens en 'n kind in nog groter mate iets van menslike geroepenheid weerspieël.

Ek kan my nie voorstel dat die mens alle bande verbreek en alle bindinge verloor het met wat eenmaal goed was en weer goed sal word nie. Die feit dat die mens sy menslike gestalte dra in weerwil daarvan dat God in 'n soortgelyke gestalte ter wille van die mens moes sterwe, en daarby dat die mens 'n ander menslike wese aankyk en hom met hierdie wese bemoei wat deur God alleen aangekyk behoort te word, laat die onwrikbare oortuiging posvat dat op die bodem van die menslike siel die onverwoesbare en die onvervreemdbare versekering lewe dat hy nie alles verloor het nie. Hy het minstens die huwelik, die Sabbat en die arbeid as van sy hoogste waardighede behou. Die skaamte wyk in die huwelik. Dit moet onderlê word deur die onbewuste herinnering uit die verborge dieptes van die siel aan 'n wêreld wat eenmaal goed was. Die eerbiedige wyk van die skaamte lei tot eksistensiële kommunikasie as skuldbesef wat liefde is. Menslike liefde het ook behoefte aan wederliefde en hieruit ontstaan die kind as produk van eksistensiële kommunikasie. Dieper gesien, is die daarwees van ' $n$ kind die herinnerende naklank en voortklank van die liefde van God wat 'n kind geword het ter wille van die mens en dus ook van elke betrokke kind. As voortklank is dit die angrypende en meeslepende voorspel tot 'n wêreld wat weer goed sal word. Die volwassene bemoei hom met ' $n$ kind en kyk dié in die aangesig om van eie skuldbesef en verantwoordelikheid bewus te word, sowel teenoor die betrokke kind as en veral teenoor Hom wat Kind geword het. Ons verstan so goed as niks van die dieptes wat die ontmoeting tussen ' $n$ wordende volwassene en 'n volwassene-wordende onderlê en waardeur dit bewerkstellig word nie. Die bietjie wat ons daarvan mag verstaan, vertolk op die een of ander wyse iets van die herkoms, die wese en die bestemming van die mens, iets van menslike geskapenheid en geroepenheid. Die fenomeen van die opvoeding behels meer dinge as wat vir menslike bevattings- en ontrafelingsvermoë toeganklik is!! Indien hierdie verskynsel ooit volledig opgediep en deursigtelik sou word, sal die herkoms en die bedoeling van die kwaad ontwar, maar ook die Kruis geloën wees. Gelukkig dat so iets nooit in die vooruitsig gestel hoef te word nie.

Is daar sin in die bemoeienis van 'n volwassene met 'n kind en skuil daar enige betekenis in om met soveel toewyding aan die toekoms van 'n kind te arbei? Hierdie vrae moet elkeen vir homself beantwoord, aangesien hulle beantwoording heeltemal buite die raamwerk en die bevoegdheid van die wetenskap val. Die antwoorde sal afhang van iemand se mensbeskouing en lewensopvatting as die totaal van denkbeelde met betrekking tot die waardevolle en nastrewenswaardige, asmede sy interpretasies van die sin van die menslike geskiedsdrama. 
Afgesien van watter lewensvisie iemand toegedaan mag wees, is 'n integrale deel van menswees die onvermydelikheid van die arbeid. Om mens te wees, beteken ook om arbeider te wees. Die lewensopvatting wat iemand huldig, bepaal sy arbeidsbeskouing en die gesindheid waarmee die arbeid verrig word. 'n Mens kan die arbeid ook beskou as die voorreg wat geniet word om steeds herinner te wees aan 'n wêreld wat goed was. Adam moes die tuin waarin God hom geplaas het, nog voor die skepping van Eva bewaak en bewerk. Om nog steeds te mag werk, is die herinnering aan 'n toestand wat eenmaal was en wat weer sal word, allermins deur die toedoen van menslike bemoeienisse. Menslike arbeid is die oprigting van tekens en bakens as herinnering aan en heen-wysinge na die grootse wat uit die gebied van die Gans-Andere in aantog is. Elke stukkie arbeid waar en van watter aard ook al, beteken vir die gelowige die aanvaarding van sy mede-verantwoordelikheid en mede-skuldigheid teenoor sy naaste. In 'n sodanige verband is alle arbeid toegespits op die bou van 'n katedraal. Om op te voed, beteken inderdaad om bouer aan 'n katedraal te wees.

Om oor die sin van die opvoeding na te dink, beteken om met die laaste wetenskaplike vrae te worstel. Die laaste wetenskaplike vrae is almal vrae aangaande die mens, maar hierdie laaste vrae is nie meer wetenskaplike vrae nie. Op die grens van ervaring en openbaring begin die mens met 'n verleë glimlag te verstaan dat die eintlike visie op die kosmos en die kosmiese gebeure waarin menslike wil en opset 'n besonder belangrike rol speel, van die menslike kant gesien darem maar die kyk deur 'n spieël in 'n ewige raaisel is. En tog kan die mens in enige en elke beslissing meehelp aan die bou van die genoemde katedraal. Dit beteken in laaste instansie verantwoordelikheidsaanvaarding teenoor die naaste wat deur God op die mens se lewensweg geplaas is. Hierin lê in finale instansie die sin van alle egte opvoeding: die oprigting van bakens om te herinner aan wat eenmaal was en om aan die hand van daardie bakens op te wek tot wat in aantog is.

C. K. Oberholzer.

Universiteit van Pretoria, Pretoria: 1954 